\title{
Aspects of Hanse archaeology in the Faroe Islands
}

\author{
SÍMUN V. ARGE
}

Arge, S. V. 2019. Aspects of Hanse archaeology in the Faroe Islands. AmS-Skrifter 27, 277-289, Stavanger, ISSN 0800 0816, ISBN 978-82-7760-183-0.

Compared to the neighbouring countries in the North Atlantic, very few sites in the Faroe Islands can be interpreted as trading sites ascribed to German merchants. This paper deals with physical evidence found around the islands that might attest to such activity. It is based on place-name evidence, local oral traditions, and, not least, archaeological remains, such as buildings and artefacts. A few sites are examined, and the presence of the Germans in the capital of Tórshavn is particularly discussed. Two of the most characteristic buildings at the peninsula of Tinganes, the Munkastovan and Leigubúðin, are reinterpreted. The site of Krambatangi on the island of Suðuroy is equally important for this discussion. Archaeological investigations took place there in 1952. The place-name as well as local tradition connected to the site suggest the presence of a merchants' booth - a trading site - located by a very fine natural harbour. The site is located close to the local assembly site in the village of Øravík.

Símun V. Arge, Tjóðsavnið. Faroe Islands National Museum. Nature and Culture. Kúrdalsvegur 15, Hoyvík, FO-110 TÓRSHAVN, FAROE ISLANDS. E-mail: svarge@savn.fo

Keywords: Hanse archaeology, trading sites, Faroe Islands, Tórshavn, Tinganes, Leigubúðin, Munkastovan, Krambatangi

The history of German trade with the Faroe islands is not well understood. Hardly any written sources of the medieval and early post-medieval period from Faroe have survived and the documents in the archives in Bremen and Hamburg, the two major centres for the German trade with the North Atlantic, rarely mention the Faroes. Direct German trade with the Faroe Islands is documented for the first time in $1416,{ }^{1}$ but other written documents strongly indicate an earlier Hanseatic interest in the Faroes. Hanseatic control over Scandinavian trade increased during the fourteenth century. German merchants held priviledged trading rights in Norway. The access to wider markets in Europe, which was provided by the Hanseatic merchants, made dried fish the largest export from northern Scandinavia. The export from Iceland of stockfish is documented in the mid-fourteenth century and, because of the lack of written sources regarding the situation in the Faroes, it is assumed that a shift from cloth, which had been the main export product, to fish also happened in the Faroes in this period. ${ }^{2}$ During the fifteenth century German merchants increased their activity in the North Atlantic at the expense of English fishermen, and the Dutch also made their appearance. We can suggest that a more regular trade with the islands was established during the latter half of the fifteenth century. In the early 1530s Frederik I of Denmark-Norway (1471-1533) enfeoffed the Hamburg merchant Thomas Koppen with the Faroe Islands, resulting in Koppen's trade monopoly. He was a councilor of Hamburg and a leading figure in the spread of the Reformation there and subsequently he played a major role in the spread of the Reformation in Faroe. Thomas Koppen was the key figure in the fight between King Christian III and the Hamburg merchants against Christopher Count of Oldenburg, Schleswig-Holstein, and the Lübeck merchants. Furthermore, Koppen served as the king's man in his struggle against the Faroese bishop for the church's posessions in the islands during the Reformation, and apparently he prepared the way for this radical religious and social change in the Faroes. ${ }^{3}$ It was not until 1709 that the Danish king took over the trade and a broader Faroese Trade Monopoly started. ${ }^{4}$ 


\section{Remains of German trading activities in Tórshavn}

Several archaeological excavations have been carried out in Tórshavn during the last twenty-five or thirty years at Tinganes, the peninsula that divides the harbour into the eastern and western bay (Fig. 1). The placename indicates that this had been the assembly site of the islands ever since the islands were first settled - first of the alting, later the løgting (the Lawthing). ${ }^{5}$ This was the main centre for the public authorities - the secular powers and, after the Reformation, also the ecclesiastical authorities. This was also the centre for commerce and trade. The trade of the islands was for shorter and longer periods under different circumstances held or enfeoffed to foreign merchants and others interested. Under the trade monopoly people were not allowed to exchange goods wherever they wanted to. They had to travel to Tórshavn from the villages spread around the islands at certain times of the year to trade and to attend the gathering of the løgting which was held a couple of days during the summer period.

Archaeological excavations in Tórshavn have all been carried out as rescue works, especially during the

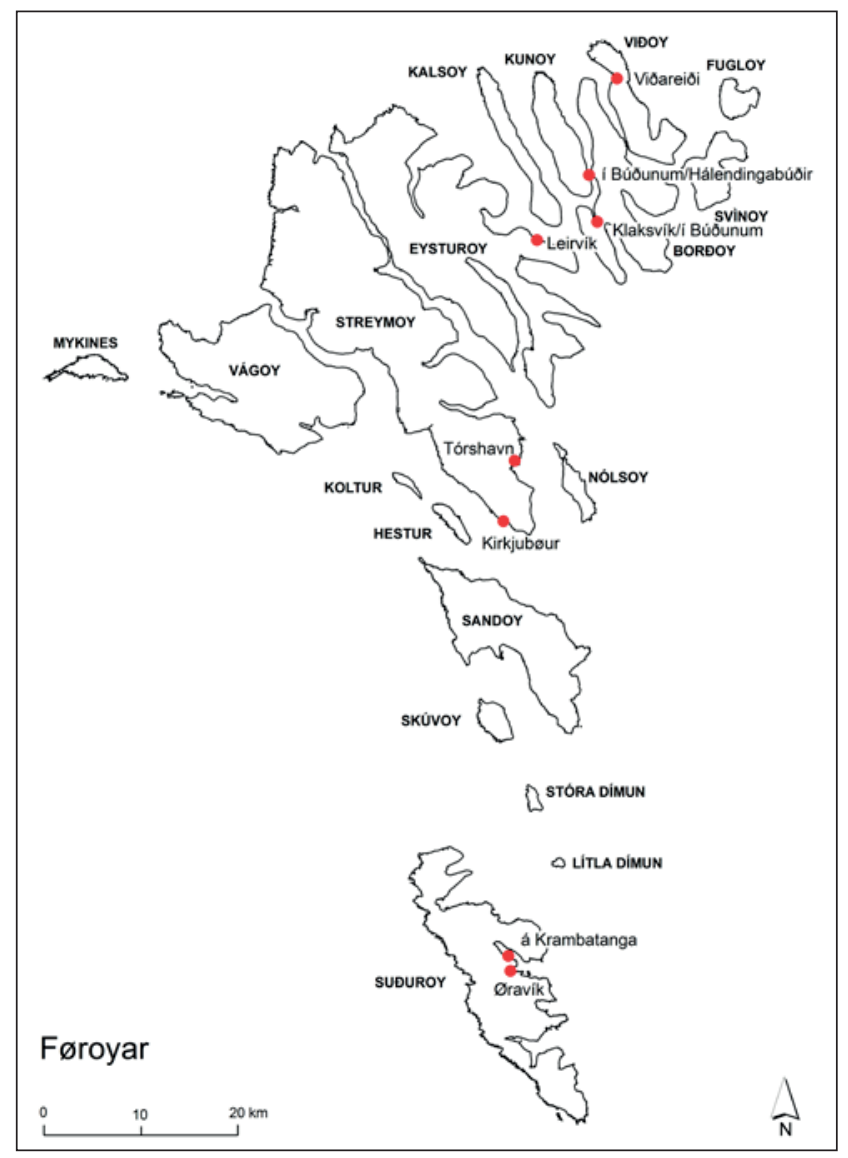

Fig. 1. Map of the Faroes with locations mentioned in the text marked (illustration: Helgi D. Michelsen). 1980s and 1990s when much construction work was done in developing the public offices in the old buildings located at the tip of the Tinganes peninsula. Many of the investigations were done as trenches; only rarely was it possible to investigate larger coherent areas. An exception was the vicars' seventeenth-century residence called Reynagarður. However, the archaeological investigations over the years have produced clear evidence of contacts the locals had with the outside world. A great amount of the archaeological material derived from the period when Germans are supposed to have been active in the Faroes. Rhenish stoneware fragments, including Siegburg, Raeren and Westerwald sherds, and fragments from stove tiles found at Tinganes can clearly be attributed to and reflect the contacts with the outside world, particularly Scandinavia and the Continent. ${ }^{6}$ However, whether this material can be seen as a direct evidence of contacts with German merchants remains uncertain. Therefore we have to ask how we can approach this question in some other way and whether the presence of German traders in Tórshavn can be identified with any certainty. One way is to look for physical evidence of maritime activity at the site. It is striking that one characteristic feature seen at Tinganes are the iron rings that are preserved along the coast, rings that have been used for mooring ships and vessels close to land from where the goods could be transported to the storehouses. The natural conditions in the harbour at Tórshavn were not good, and therefore many of the ships had to be moored off the coast using iron chains attached to such rings. The goods had to be freighted to land by smaller boats or lighters, a practice which continued up to quite recent times. However, ships were also able to lie alongside the shore loading or unloading cargo at the crane or derrick on the shore - the so-called Vippa, the Seesaw, which still is preserved in situ (Fig. 2).

Unfortunately, no medieval written sources refer to Hanseatic activity on Tinganes, but from sixteenthcentury sources it is apparent that warehouses existed there and had done so for years. These sources refer to buildings or warehouses which belonged to the Royal Monopoly. ${ }^{7}$ According to Lucas Debes (1623-1675), the dean who arrived in the Faroes in 1651 and who drew upon oral tradition, Hamburg merchants were the first to have their warehouse here and after them came traders from Bergen. ${ }^{8}$ In an earlier paper I had come to the conclusion that we do not know where the Hanseatic warehouse was located at Tinganes: no traces of a Hanseatic building had been identified there, due to the fact that the area apparently has been 


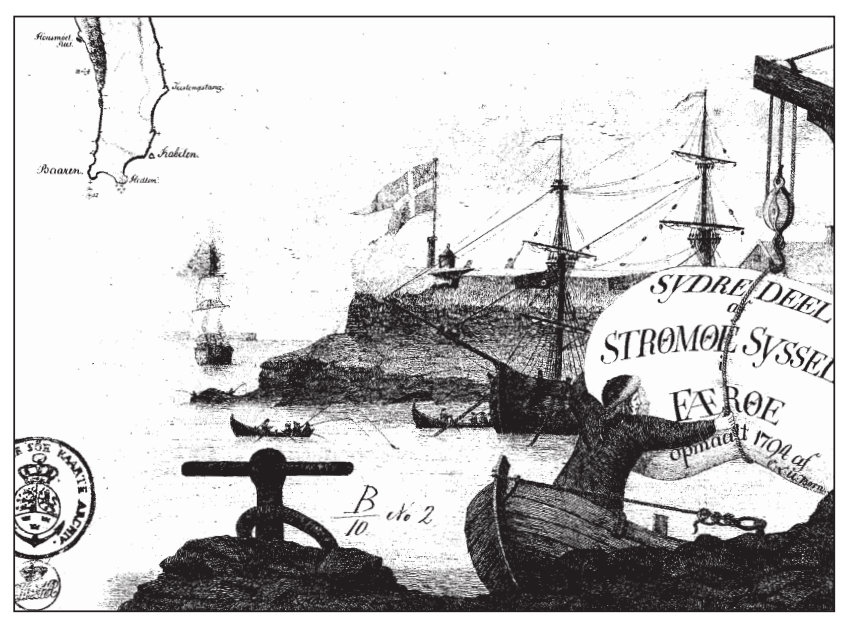

Fig. 2. Tórshavn as depicted by Captain L. Born 1794. The ship is unloaded by the so-called Vippa, the crane at the jetty at Tinganes. In the background we can see activities on the eastern bay of Tórshavn and the fort at Stangarnes, Stóriskansi. The fort was thoroughly reconstructed by Born during the 1780s.

heavily disturbed and redeveloped many times. ${ }^{9}$ We also have to take into account the great fire that ravaged the area on 30 January 1673 when the turret of the fort, Litli Skansi, containing the gunpowder exploded and almost all the buildings belonging to the Trade Monopoly burnt down, even the krambod (shop), the Landskyldbod (the land dues booth) or Købmandens Landskyldbod, as it is named in written records (i.e. the merchants' or the trading post manager's booth) - not to be mistaken for the Kongens Landskyldbod or Hans Majestæts Landskyldbod, the King's or His Majesty's Landskyldbod - the merchants' dwellings, three logbuildings and the cooperage. In spite of this immense fire, Hans Majestæts Landskyldbod (royal rent collection booth) - in Faroese called the Leigubúðin - the

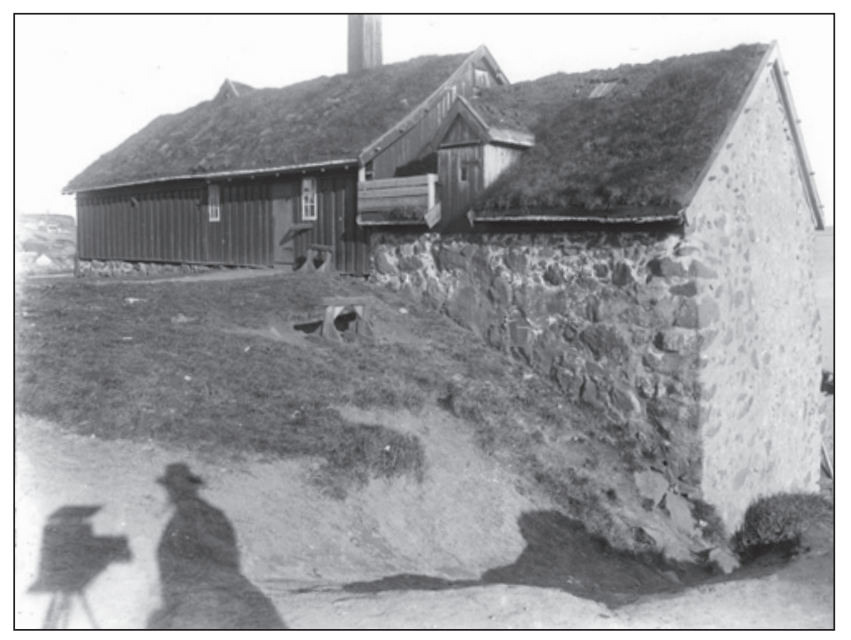

Fig. 3. The building named Munkastova in Tórshavn, as photographed by J. Klein in 1898.
Munkastovan (monks' dwelling), the school, the church and the vicars' buildings, Reynagarður, all located further uphill on the peninsula, escaped the fire. ${ }^{10}$

Let us now turn to the physical remains on Tinganes that escaped the fire, to consider whether any of those may have been part of the trading station of the preceding period. It is possible that buildings made of timber, a relatively perishable material in the humid Faroese climate, may have been lost since the accident. Equally, it is also possible that some of these buildings may have been so substantial in their constructions that they are to be found amongst the historical remains still visible on the peninsula. Potential candidates amongst the still-standing buildings at Tinganes are those known as the Munkastovan and the Leigubúðin, which differ from the other buildings.

\section{The Munkastovan and the Leigubúðin}

The building that bears the popular name Munkastovan has always attracted great attention, not least for its architecture and date. ${ }^{11}$ In contrast to the other buildings at Tinganes, this is a wooden construction resting on a basement made of stone and lime-mortar formed from burned sea shells, a building technique that in the Faroes only has a parallel at the medieval bishopric in the village of Kirkjubøur located on the western coast of the island of Streymoy, the neighboring village of Tórshavn (Fig. 3). Today Munkastovan appears as a $7.5 \mathrm{~m}$ long and 5-6 $\mathrm{m}$ wide structure orientated east to west. It has always been regarded as a two-storey building with a light wooden roof raised in 1705 sitting on plastered stone walls $1-1.5 \mathrm{~m}$ broad. ${ }^{12}$ The southern wall is rendered with a thick layer of plaster and seems to be rebuilt. The windows sit in the wooden parts of that wall and are obviously of more recent origin. The western wall seems to be rebuilt. In 1732 the building consisted of a basement on top of which were two storeys, measuring $4.39 \mathrm{~m}$ by $5.65 \mathrm{~m}$ (7 by 9 Danish ells), with one sitting room and a kitchen on each floor. On the outside there was a staircase leading to both floors. ${ }^{13}$ The Leigubúðin is attached to its eastern gable end, and a warehouse, named Skibsteds Pakhus was added in 1899 to the western gable end. ${ }^{14}$

The Leigubúðin or Landskyldboden, as it is named in the Danish written records, measures $15.5 \mathrm{~m}$ by $5 \mathrm{~m}$ internally. The width varies by half a metre, though it is broadest in the western end. These measures are in accordance with the written records from 1709. The wooden building, erected on a basement of stone and 


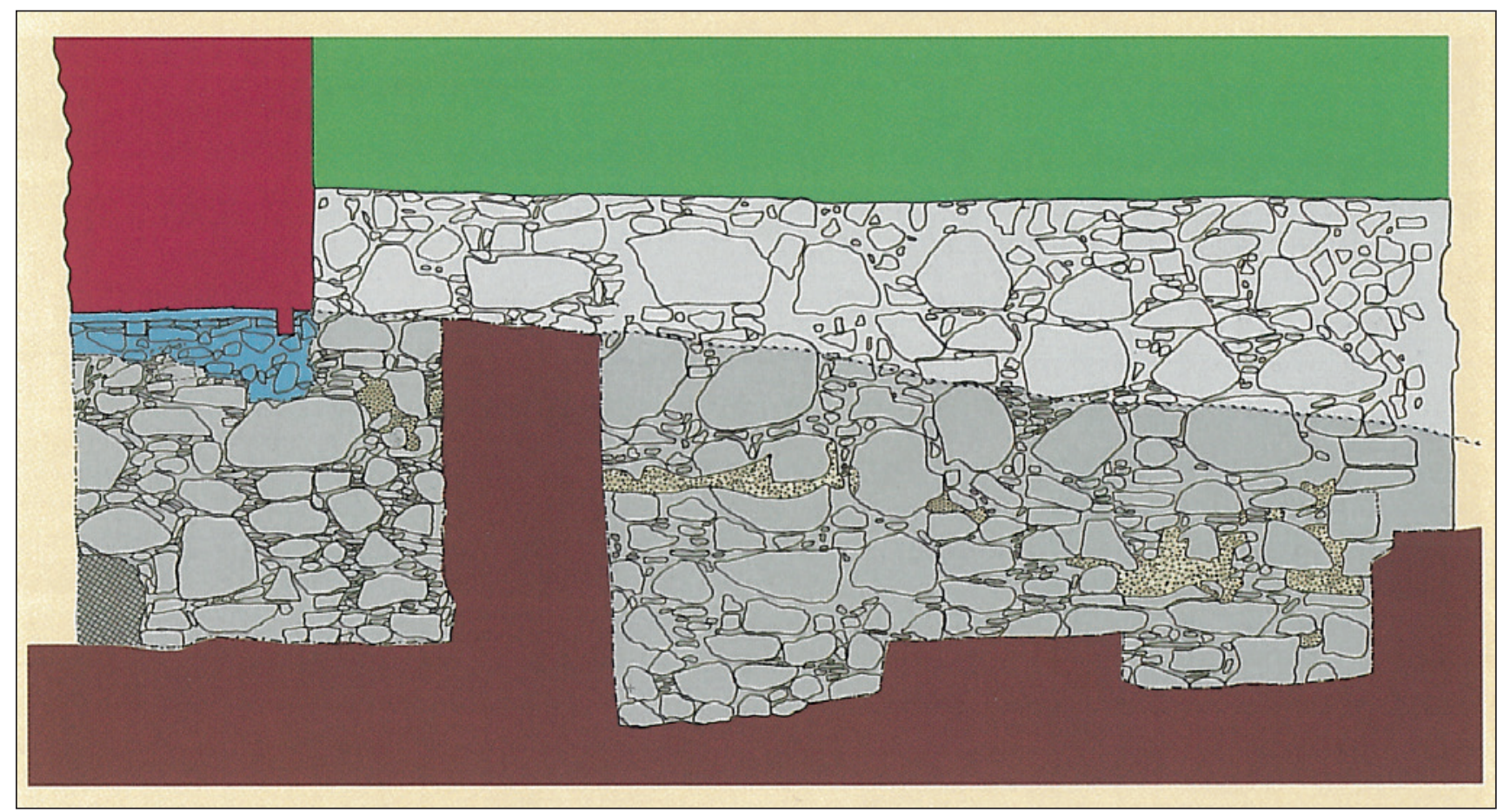

Fig. 4. Elevation of the northern stone wall of Munkastova and Leiguburdin according to the excavation in 1988 - west is on the right hand; marked green: the roof of Munkastova; marked red: the western end of the wooden northern wall of Leigubúðin; marked blue: stone sill on which the northern wall of Leigubúdin rests; marked yellow: fragments of lime (skilp) on the ouside of the stone wall; marked light grey: the stone wall which is above ground level today; marked brown: not excavated (illustration from Arge and Michelsen 2004).

lime mortar, was constructed in $1732 \cdot{ }^{15}$ Originally, this building had just one floor, the stone basement with a wooden roof on top. There were two rooms in this stone building with wooden panels and floor. Because of humidity problems caused by water seeping in from the churchyard on the northern side of the building, a wooden floor was built in 1732 on top of the basement. This was for commodities that had to be kept in dry storage, while the basement was used for barrels and wet commodities. ${ }^{16}$

Archaeological investigations in 1988 directed by the present writer established that Munkastovan was originally a building of more impressive dimensions. ${ }^{17}$ It was demonstrated that the northern wall, erected of larger stones laid in a locally produced mortar named skilp, continues towards east below the wooden Leigubúðin, which, as previously mentioned, continues east of the gable end of Munkastovan (Fig. 4). ${ }^{18}$ This implies that the base sill of Leigubúðin, at least on the northern side, is founded on the northern stone wall of Munkastovan. This information is crucial as it proves that Munkastovan was a somewhat larger building than it appears today, with a length of at least $12 \mathrm{~m}$. How much further towards east the stone wall goes is unclear because of the limits of the excavated area on the northern side. Information regarding the original extent of the building has to await future investigations of the masonry and the ground.

In 2004 an archaeological excavation was undertaken in the basement of Leigubúðin. ${ }^{19}$ A stone pavement was exposed with traces indicating a possible division of the basement into several separate rooms. Furthermore, there were timber constructions of quite considerable dimensions arranged vertically along the inside of the stone walls. The investigations indicate that this may have been a warehouse.

The questions arises whether Munkastovan and Leigubúðin originally may have been one large building. If so, an apparently monumental $23 \mathrm{~m}$ long stone building was placed across the Tinganes peninsula, demarcating the churchyard towards south, and with its western gable-end placed close to the sea at Skinnaraskerd, the skinners' rock. Interestingly, the water between the rock and the Tinganes peninsula is named Punthavn, 'punt' referring to a point, so that the name may be translated as the harbour at the point'. The same name is also found close to the site of Krambatanga on Suðuroy, a site that is discussed in more detail below. However, the sea here is quite shallow, so the suitability for loading and unloading cargo 
may not have been the best if the conditions have not changed since the Middle Ages (Fig. 5).

It has not been possible so far to date Munkastovan. The first evidence of the name Munkastovan is recorded in 1670, though there are indications of the name back in $1619 .{ }^{20}$ The construction of the stone walls indicates that the building may be older than most or, indeed, any other of the standing buildings at Tinganes. Its closest parallels are to be found amongst the buildings of stones laid in lime mortar at the site of the medieval episcopal see in Kirkjubøur, especially the small church named Líkhús. That church was apparently under construction in the $1420 \mathrm{~s} .{ }^{21} \mathrm{~A}$ dating of the building to the late or even the high Middle Ages therefore is highly possible, though this needs to be verified through future investigations, such as through dendrodating of the wooden constructions in the basement. ${ }^{22}$

Another relevant question is who erected the building and for what purpose? This question has often been touched upon, most recently when the aforementioned investigation was presented in a chapter in a book on Tórshavn's history ${ }^{23}$ and in a master's thesis. ${ }^{24}$ According to local narratives, Munkastovan was the storage for commodities that belonged to the bishops, when they were off-loaded. ${ }^{25}$ However, this connection may be due to the building's unusual appearance and building technique. In 1673 Lucas Debes informs us that by then Munkastovan was an old building used as the merchants' or the trading post manager's warehouse, while Leigubúðin was the king's Landskyldbod (land dues booth). In fact, these functions may not have always been so, but may have changed over time. It is striking, however, that Munkastovan is not mentioned in written records until 1670 . This could be due to the fact that the building was not used either by the landfoged (the administrative officer), nor the merchants until sometime between 1620 and 1670. Here we have to keep in mind that the records in question only comprise buildings that belonged to these persons. Therefore, this opens up the possibility that the merchants may not have taken over the Munkastovan building which until then belonged to a third party.

It seems reasonable to consider whether this building, with its striking appearance differing from the rest of the buildings at Tinganes, and its very individual appearance in the wider contemporary environment, may have had its origin in the activity of the Germans in town. Indeed, could this building have served as the main office of the Germans in the Faroes? ${ }^{26}$ The building is of such considerable dimensions, $23 \mathrm{~m}$ by $5-6 \mathrm{~m}$, that it may very well have served as a dwelling, as

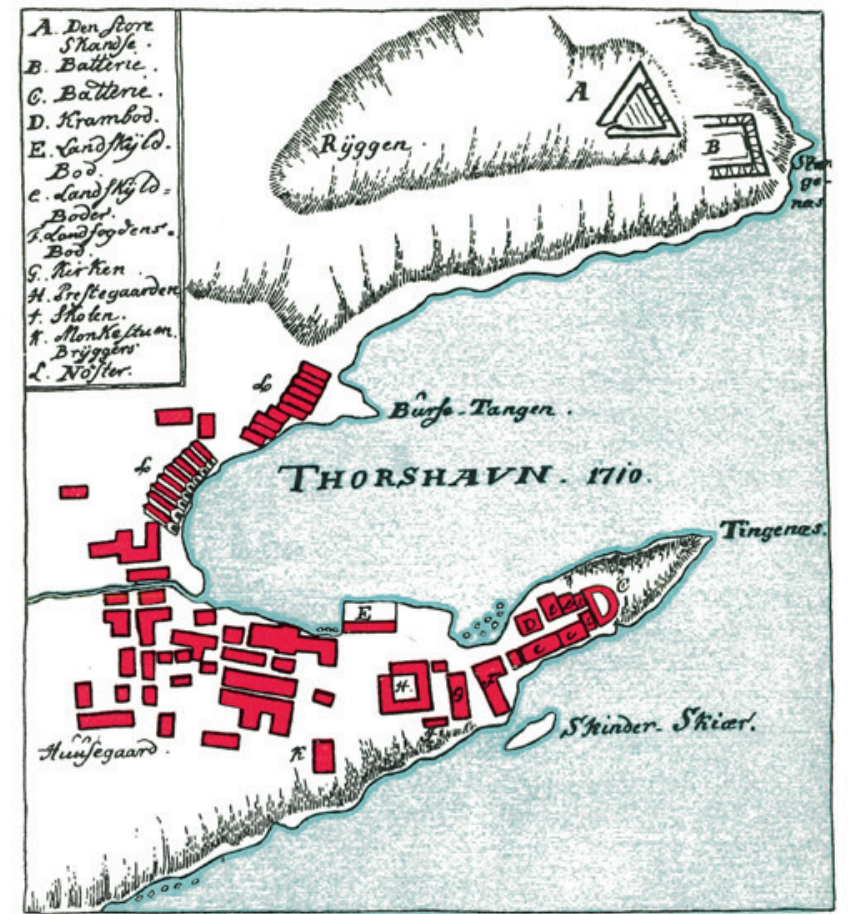

Fig. 5. Tinganes at Tórshavn as depicted by Rasmus Juel in 1710. Munkastova and Leigubuidin (F) in their environment: the church (G), the churchyard in between $F$ and G, Reynagardur (the vicars' residence) $(H)$ and the school (f). Further out on the peninslua are the trade buildings, and right on the tip is Litli Skansi, the battery named Little Fort (C). Stóri Skansi, the Large Fort (A), is on the other side of the eastern bay. Notice the rock, Skinnaraskerd, in the western bay just off the coast by the Munkastova. The area between Skinnaraskerð and the peninsula, Tiganes, is Punthavn. According to the map K is Munkastova, but this is incorrect. Munkastova is part of F (illustration from Andersen 1964).

well as a warehouse, and it may have been in use both summer and winter. Overwintering was prohibited, but at least in Iceland, exceptions granted by the local authorities are known. ${ }^{27}$

Compared to German buildings in Shetland, the so-called böds, it is apparent that we find similar stone buildings representing this activity, although much smaller in size, in the so-called Bremen böd in Symbister on Whalsey ${ }^{28}$ and the early building at Busta House on western Mainland. ${ }^{29}$ These two buildings have even had small harbours connected to them, an arrangement which may have been true at Tinganes as well. Anyway, these examples and others too show that the Germans were not unfamiliar with this type of architecture in the North Atlantic. But, a final resolution regarding Munkastova and Leigubúðin, their appearence, construction, size and furnishing, 
has to await a thorough building and archaeological investigation.

\section{A possible trading station at á Krambatanga, Suðuroy}

In August 1952 Sverri Dahl (1910-1987), the then state antiquarian and director of the National Museum of the Faroes, Føroya Fornminnissavn, carried out a minor investigation at a site called á Krambatanga by the fjord Trongisvágsfiørður on the southernmost island of the Faroes, Suðuroy (see Fig. 1). The archaeological material which was revealed during this investigation has actually never received much attention, at least not as much as it may deserve. Until quite recently it has just been gathering dust in the storage of the museum in Tórshavn. ${ }^{30}$

Trongisvágsfiørður is the deepest fjord in the Faroes (Fig. 6). Towards the centre of the southern arm of the fjord, in the outfield of the village of Øravík, is a site called Gálgatangi, the gallows' tongue or point. Furthermore, at Gálgatangi there are the names Innarigálgi, the inner gallows, referring to the direction in relation to the fjord, and Heimarigálgi, the nearer gallows, referring to its position in relation to the village of Øravík. Along the coast further into the fjord is first Byrgishavn, the harbour of the byrgi or enclosure, which is marked by a stone-turf dyke crossing the point at Gálgatangi, fencing it in for special agricultural purposes. Next to it is Punthavn, the harbour at the point, a name which was noted during the discussion of Munkastovan at Tinganes in Tórshavn. Then comes Krambatangi, meaning the headland with booth or shop.

According to local tradition the Hanse and/or the Dutch had a krambod, a shop or a booth, on this site, hence the placename, Krambatangi. It is, however, uncertain when this happened, though, some hundred years ago is suggested. Interestingly, oral tradition has it that these people also dried fish at the site. This wellprotected site has a fine little natural harbour, very suitable for larger vessels than the traditional Faroese boat (Fig. 7). The location and its surroundings are not only referred to in oral tradition, but often occur in written records from the late sixteenth century onwards. Different authors in the seventeenth century write that the bays by the fjord of Trongisvágur are excellent places for boats to be laid up for the winter. ${ }^{31}$ Lucas Debes describes the local circumstances as '...quite well inside the fjord is a very good harbour, named Punthavn; also a holm in between and the shore, where the ship can be moored with ropes, and a plank on which it is possible to enter the shore. Further, the fjord is a good summer haven. ${ }^{32}$

The situation was the same in 1709 when the possibility of placing a department of the recently estabished Royal Monopoly in Tórshavn on Suðuroy was assessed. It was then stated that the location, where, it was said, there was a shop a long time ago, is the best harbour in the islands. Because of the long distance to the main station in Tórshavn, the site was very vulnerable to foreign raids by sea and these plans were cancelled by the royal commission dealing with these issues. ${ }^{33}$ Later writers mention a shop here, and they all place it 'by the Punthavn', which apparently may have been a joint term for all the area along the coast. Therefore, it is obvious that the local people for centuries have been aware of that at one time some kind of activity took place at this site, apparently commerce, but when this activity took place has been difficult to confirm.

The discovery of a certain artefact provided further confirmation of this. In May or June 1913 an elaborate wooden $47 \mathrm{~cm}$ long figure of Christ, once part of a crucifix and apparently a seventeenth-century Dutch piece of art, was found by chance during the collection of stones for ballast at the beach just west of the site of Krambatangi (Fig. 8). ${ }^{34}$ This was taken as an indication of the foreign activity in the area, seemingly verifying the legends and oral traditions.

How long the site had been frequented by German and/or Dutch merchants, and when it was founded, are uncertain. Some are of the opinion that in 1656 trade stopped at Krambatangi when the Icelandic Company established a new trading station nearby. ${ }^{35}$ However, there is no known primary evidence for this, though it is obvious that activity took place at this period to provide a supply of goods to the island of Suðuroy.

Today the site is clearly visible as a ruin or structure consisting of a grass-grown mound. The ruin had been damaged previously, in 1932 when the shipowner and merchant in Tvøroyri, Tummas Thomsen, built a storehouse on the opposite side of the fjord. On that occasion fragments of redware pottery were found. Again, in 1944, when another owner of the site, a local boatbuilder Viggo Mortensen, made a passageway for a new-built boat, some forty yellow bricks were found together with other things as well. Finally, in 1952, the boatbuilder had to widen the passageway which was cut right through the ruin again revealing artefacts, such as a fragmented lead bullet or weight, a piece of chalcedony and some small opals. The National Museum in Tórshavn was informed and Sverri Dahl, the State 


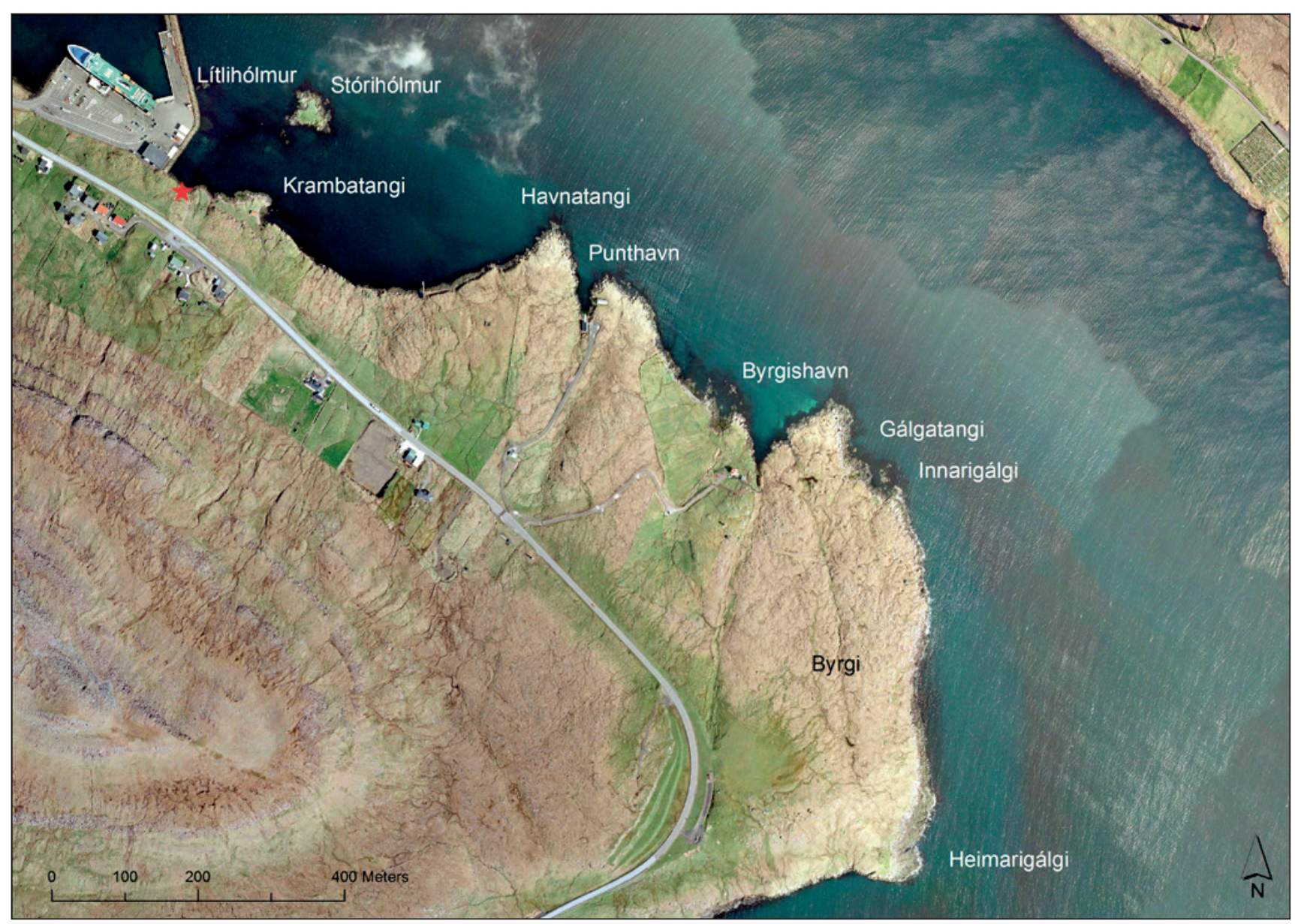

Fig. 6. Aerial photo of the southern arm of the fjord of Trongisvágsfjødur with the site of Krambatangi and place names in that area marked (illustration: Helgi D. Michelsen).

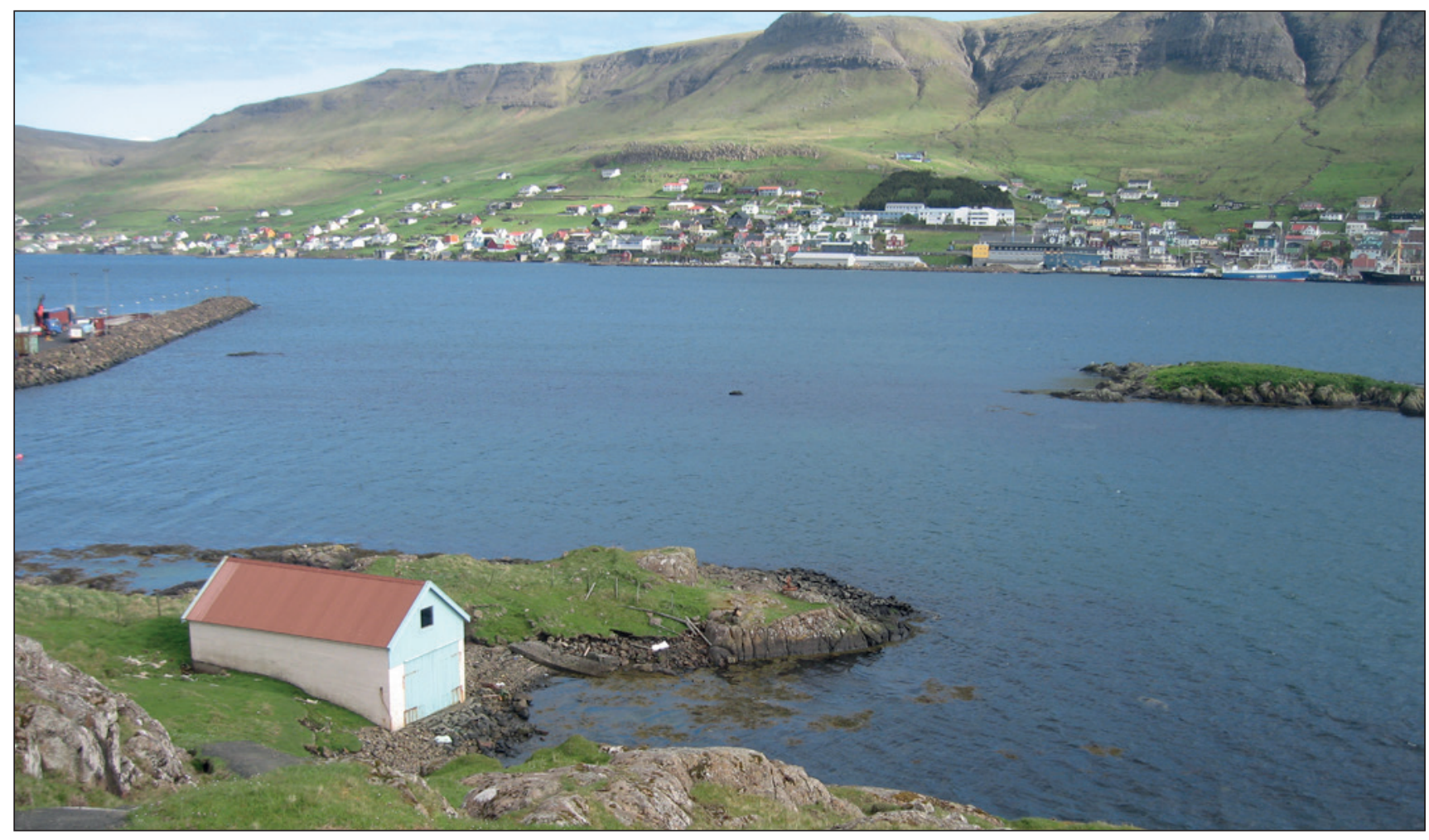

Fig. 7. A Krambatanga, the site of a German and Dutch trading station (photo: Simun V. Arge, 2008). 


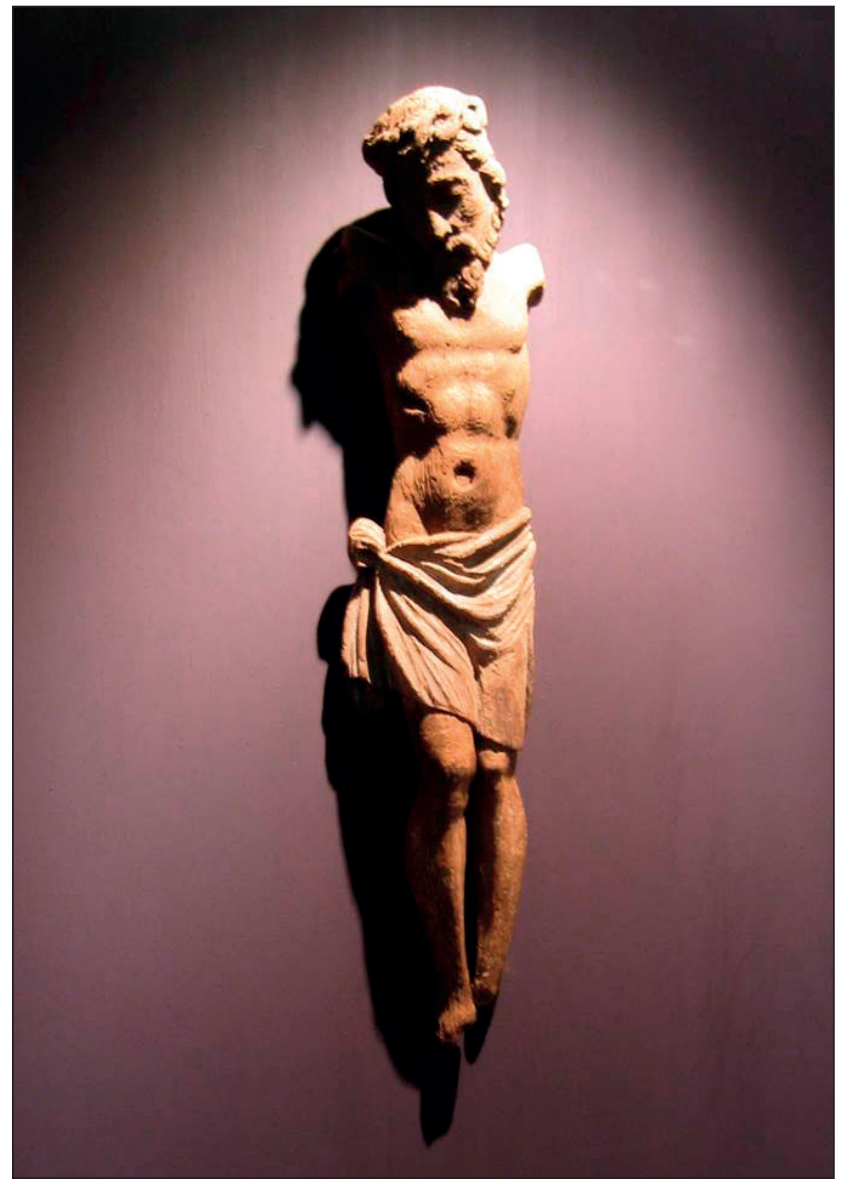

Fig. 8. Wooden crucifix found in 1913 at the beach by a Krambatanga (photo: Símun V. Arge).

Antiquarian, got the opportunity to undertake a minor excavation from 11.-23. September of that year, revealing a ruined building and a few artefacts. The building that came to light was some $10 \mathrm{~m}$ long and $4 \mathrm{~m}$ wide and had 1-1.5 m broad walls built of stone and gravel, preserved to a height of $0.5 \mathrm{~m}$. The 1944 boat passageway runs through the centre of the building. The floor of the building consisted of wooden planks over a stonebase. Clearly, there were other structures attached to the building, but they were neither excavated nor interpreted.

The excavation provided only a small number of artefacts. Amongst them were four bars of schist for the preparation of whetstones, two fragments of gunflint and two lead bullets, one of them having being fired. Eight large brick fragments had been found by earlier activity at the site. Three ceramic fragments were also found, two of them coming from redware pots with brownish glaze, and one fragment of a fine and small slipware bowl of Werra Ware, showing the date 16[..]. The production of Werra Ware in Germany came to an end during the Thirty Years War (1618-1648) and it is thus justifiable to date the fragment to the first half of the seventeenth century. The most interesting find is probably a complete touchstone used for assaying precious metal alloys, mostly gold and silver. Geologically, it is a so-called mudstone. It has a finely grained surface on which soft metals leave a visible trace, as can be seen with the scratch marks on three of its sides. ${ }^{36}$ All of those finds are evidence of trade at the site. None of the artefacts is made of an indigenous raw material and all are imported. The schist bars most likely originate in Norway. During the late medieval and early modern period, this kind of raw material was part of the multilateral Hanse trade, the bars being bought by Hanseatic merchants and then distributed further. ${ }^{37}$ The pottery fragments are difficult to interpret. The origin of the redware fragments is not known exactly, but it is most likely that they were produced in either Denmark, Northern Germany or the Netherlands. Werra Ware was exported from the Werra area in present Lower Saxony, Germany, to the Netherlands in great quantities, and the bowl could thus have been transported to the Faroes by either the Germans or the Dutch. ${ }^{38}$ The brick fragments could be of Dutch or German origin. The occurrence of a touchstone at the site is truly remarkable. It is a merchant's tool, often carried in a bag or purse at the belt, sometimes fastened in a sheath. ${ }^{39}$ Its origin and date are unknown but it must have belonged to a merchant who used it for assaying the metal value of coins he got in exchange for his goods.

With the exception of the Werra Ware and redware fragments, all other artefacts are hard to date. However, they point to a main occupation period of the sixteenth and seventeenth century; the sixteenth century being the main period of the German activities on the Faroe islands, and the lead bullets could be witnesses of the many pirate raids to which the trading site, according to local legends, was exposed during its existence. We need to bear in mind, however, that the excavation from 1952 apparently uncovered only the occupation layers from the latest use of the warehouse. Thus, the construction date of the building and the first phase of use still needs to be verified and investigated by further excavation. A trading place consisting of one or two buildings only, might seem unusual, but many German trading stations in Iceland and Shetland were of the same size. The buildings operated only in the summer during trading season and were mostly used as warehouses while the crew stayed on the ship. ${ }^{40}$

Further remains deriving from the trading activity on the site are still visible in the surroundings. On the site, as well as on a small holm just off the coast, 
Stórihólmur, and on a small skerry, Lítlihólmur, iron rings of various sizes used for mooring boats and ships still exist today. This evidence of maritime activity was also noted in the discussion of the site at Tinganes, Tórshavn.

Even if the archaeological record at Krambatangi does not differ much from what has been found during archaeological excavations at other sites on the islands, it has to be noted that the location at Krambatangi is quite special. Here we find a minor structure located in the outfields outside the traditional settlement. Apart form the Viking shieling sites, all other settlements are connected to the existing historical settement at or by the so-called heimrust within the infields - the place where buildings traditionally were erected. On the other hand, the site is located close to the activities of the local assembly site in the village of Øravík. ${ }^{41}$ Therefore, the location at Krambatangi is quite characteristic and it has been dealt with in earlier work. ${ }^{42}$

\section{Other archaeological remains and place names}

Apart from the two previously mentioned localities we have to accept that archaeologically there does not seem much left for us to build upon. Though, we have to recognize that we have not traced possible remains which might derive from German activities by a systematic survey of the landscape with this purpose in mind. From the evidence in the neighbouring areas in the North Atlantic, one would expect to find widespread remains from this activity in the islands. The encouraging results from investigations made in Shetland and especially from Iceland through studying evidence other than historical and archaeological sources, is that from certain types of place-names, we may be able to approach the issue regarding foreign-related activity in the Faroe landscape as well..$^{43}$ Investigations of the Faroese place-name material regarding the issue has so far only been touched upon. Briefly, I will draw attention to one special place-name element that marks itself out from others, that of $-b u \dot{ }$ (Engl. booth). The place-name, Krambatangi, earlier referred to in this paper, comprises the element - $b a$. Apparently, this element derives from the the word -bod, in Faroese -búd, which is why the interpretation of Krambúðartangi means 'the headland with the shop'. We find the same element in words like í Búðunum within the town of Klaksvík on Borðoy in the northern part of the Faroes (see Fig. 1). It is now impossible to identify any form of remains from earlier settlement or activity on the the site because of modern development on the site of í Búðunum in Klaksvík, but interestingly, according to local legends the Dutch stayed at the site sometime in history. ${ }^{44}$

It is worth noting another site with the same name í Búðunum, also called Hálendingabúðir, 'the booths of the Dutch', located in the outfield by the coast a few kilometres south of the village of Haraldssund on Kunoy, the neighbouring island of the aforementioned Borðoy (see Fig. 1). There are visible remains of at least two ruins, as well as stone-dykes at the site. As the site has neither been surveyed, nor investigated, it is difficult to interpret and even now there are remains, both those still visible, as well as those perhaps hidden below the grass. Local legends has it that the Dutch lived here. ${ }^{45}$ Another explanation of the word is that Dutch merchants who conducted illicit traffic lived at the site in the sixteenth and seventeenth centuries, ${ }^{46}$ and yet another explains the word by referring to the same local legend as the one mentioned above pointing to the Dutch, though the explanation in that case is that this is a deserted farm site. ${ }^{47}$

Is it possible that the place-name really indicates the presence of Dutch merchants at the site, or are they quite simply derived from an abolished medieval farm? ${ }^{48}$ In favour of the first interpretation is its location in the outfield and that there apparently is no real infield attached to the site, though some kind of cultivation may have taken place close to the ruins. Further, here there are no place-names indicating a seasonal settlement, such as the Viking -argi/-ergi. ${ }^{49}$ On the other hand, the site is not connected to the assembly activities in that area as we have noted both on Suðuroy and in Tórshavn, so the function of the site remains unclear until the site has been investigated properly. This location quite clearly is a subject for closer investigation regarding the activities of the Hanse in the Faroes.

We have noted that the place-name element -búd is sometimes attached to commercial activity. But we also have to be aware that this name element frequently occurs as a name of a house at a traditional farm or even of a farm itself, that is in an agrarian context, as in names like uppi í Búð, niðri í Búð, innar í Búð’ or í Búðini.

\section{Discussion}

In the light of the progress of the Germans during the fifteenth and sixteenth centuries with their expanding commercial interests in the North Atlantic region 
and the lack of written sources, the importance of the archaeological evidence from this period for the Faroes is clear. According to the Faroese archaeological record from the High and Late Medieval Period, the inhabitants were reliant to a great extent on imported goods implying foreign contacts. Some of the goods had to be imported because they were made of raw materials that quite simply did not exist on the Faroes. Typically, these were made of different types of schist, such equipment and domestic goods as hones of mica and clay slate, vessels of steatite of different sizes, as well as the typical baking plates of a schistose soapstone. All of these seem to have been produced in Norway during the Medieval Period. Here we also can add the import of querns of a soft mica shist apparently from western Norway. ${ }^{50}$ Further, ceramics have been found that have their origin on the European continent, such as types as Paffrath and Andenne. Later, in the sixteenth and seventeenth centuries, we find lots of household products, domestic table wares which in our neighbouring countries are characteristic of the Renaissance and the post-Reformation period, such as the well-known decorated red glazed earthenware, as well as stoneware vessels. These may have been produced in Scandinavia, as well as in northern Germany. As timber for building purposes did not grow locally, we may expect that a great amount of timber must have been imported during the period in question, as it had been earlier. ${ }^{51}$ Iron objects are quite frequently found during archaeological excavations, most of which must be expected to be imported, though local smithing seems to have been a regular craft and, even though our knowledge regarding possible local iron extraction is limited, the constant need of iron is clearly evident in post-medieval written sources. ${ }^{52}$

As mentioned earlier, many of these wares are imported from Norway. Further, it is supposed that during this period in question the wares have reached the Faroes from the city of Bergen, though we in the later part of this period may expect imports from Copenhagen and Germany, and that they may have been stored in warehouses built for that purpose at Tinganes where we may imagine that the importers and merchants - probably Germans - stayed. Later, the wares have been purchased and spread to the farms around the islands who had a need and a demand, as well as proper financial surpluses for purchasing these goods. A good example from an agrarian environment in this respect is the site of 1 Uppistovubeitinum in the village of Leirvík, Eysturoy. The site is characterized as a normal farm mound covering settlement remains and cultural layers mainly from early Middle Ages and into the fourteenth century. Here, the archaeological record indicates a large number of imported goods, such as ceramics produced in Paffrath and Andenne, and bone combs. ${ }^{53}$

A great amount of Renaissance material has been found at Tinganes. Though we here observe modern trends in the goods, it is difficult on the material available to decide whether it has been imported by German merchants or by other commercial activity. As has been seen in other locations in Scandinavia and on the continent where German merchants were present, the Germans very well may have been innovators in the use of these wares, and set the trends in Tórshavn creating an urban environment in the capital and secular centre of this small island-community, with a population size of around 4000 around the year 1600 , with commodities that were up-to-date for that time. ${ }^{54}$

In addition to a main German trading station in the capital, there may have been a need for other trading stations, namely in the south and in the north. Here Krambatangi on Suðuroy and another one at í Búðunum on Borðoy, now Klaksvík, would make sense. These places are far away from Tórshavn, and after all in Shetland the Germans got their trading licences in various places in order to supply the local population. ${ }^{55}$

Another location where an urban environment could be expected during the same period is at the bishop's residence in Kirkjubøur, the neighbouring village of Tórshavn. It is usually named as the ecclesiastical and cultural centre of the islands with both ecclesiastical and secular contacts on the continent. The great building activities at the medieval bishopric in Kirkjubøur during the thirteenth to fifteenth centuries, where buildings, three churches as well as the bishop's residence were erected of stones laid in lime mortar, which was in strong contrast to the local traditional wooden architecture, ${ }^{56}$ and has in recent years been interpreted as a result of the bishops' engagement in commercial affairs on the Faroes. ${ }^{57}$ An explanation of this might be found in the great European economic interests in the rich fish resources in the waters around the Faroes in which the Hanse, no doubt, were interested. ${ }^{58}$ The fact that the measuring units and calculation system also changed during this period has been seen as the result of foreign commercial influence from the North Sea region indicating a change in the main export products from agricultural products to fish products. ${ }^{59}$ But how large the roles of the bishops were compared to the merchants living in Tórhavn is impossible to determine based on the sources at hand. 
So far, the written records have not been very informative regarding these matters. Different kinds of foreign impact in Faroese medieval society have been stressed elsewhere. These included issues, such as Nordic and European church politics and politics in general from the period we are dealing with here. This makes us see a growing clerical commercial interest, in the installation of German bishops on the Faroe Islands during this period. However, this period has so far only briefly been considered by historians and archaeologists. ${ }^{60}$

It has not been possible to obtain information from the archaeological material that was found during the Norwegian-Danish-Faroese excavations 1953-1955 in Kirkjubøur, simply because it has never been analysed. Besides providing an insight into the local society, an analyses of the material would give information regarding the daily life and probably also commercial activities, elucidating the question of the involvement of the bishops. My personal feeling is that the material is characterized by artefacts representative of the Renaissance and post-Reformation, that is by lead glazed earthenware stove tiles, more than those of the medieval period. To gain a better understanding of the bishops' role in the trade of the Faroes compared to that of the merchants' with their domicile in Tórshavn, the archaeological material found in Kirkjubøur needs to be analysed. Besides that, we need a critical examination of the relationship between the contemporary neighbouring centres, the secular Tórshavn and the ecclesiastical Kirkjubøur in the late medieval period and the time around the Reformation.

As may be evident, it is not an easy task to decide whether the presence of certain imported artefacts or goods in the Faroes are due to the contact with German merchants. Other circumstances may have played a role. But you can hardly have any hope to find such a palpable example as the small wooden late Gothic crucifix in the church in the village of Viðareiði on the northerly island of Borðoy (Fig. 9). On the crucifix is painted 'Thomas Koppen 1551', that Hamburg merchant who held a trading monopoly with the Faroes in the first half of the sixteenth century (mentioned above). The crucifix is probably a gift to the church, obviously in the hope of maintaining good relationships with the Almighty.

Note: After the submission of this manuscript five samples from the wooden construction in the basement of the Leigubúðin were dendrochronologically dated. The dates of the timber are all post-medieval. So far the dates from the Leigubúðin have not been evaluated and discussed in a building-archaeological context. Until then I stick to my considerations expressed in the text regarding the masonry in the northern wall of the Munkastovan/Leigubúðin observed during the archaeological investigations in 1988.

The dating was undertaken by Thomas Seip Bartholin in 2016 within a dendro-project regarding some of the older buildings at Tinganes, Tórshavn, and at the Medieval bishopric in Kirkjubøur. (J.no.: NNU A9086. Dendrokronologisk undersøgelse: LEIGUBUDIN, Tinganes, Torshavn. Foreløbig rapport. 13.11.2016 Thomas Seip Bartholin).

\section{Acknowledgements}

I would like to express my warmest thanks to $\mathrm{Dr}$ Natascha Mehler, Deutsches Schifffahrtsmuseum Bremerhaven, for inviting me to the Avaldsnes conference and getting the opportunity of meeting colleagues and researchers dealing with the Hanse issue in the North Atlantic. I also wish to thank her and Dr Mark Gardiner, University of Lincoln, for reading through and commenting on the manuscript, for discussions and fruitful collaboration within this project. Uni Árting, geologist at Jarðfeingi, Faroese Earth ad Energy Directorate, is thanked for the geological identification of the mudstone from Krambatangi; Eivind Weyhe, Assistant Professor emeritus, and Kristin Magnussen, PhD candidate, both the Faculty of Faroese Language and Literature, the University of the Faroe Islands, for discussions and information regarding Faroese placename evidence relevant to this issue; Dr phil. Erla Hohler, professor emerita, University of Oslo, Kristin Kausland, PhD candidate, University of Oslo, and Ebbe Nyborg, editor, Nationalmuseum in Copenhagen, for information and discussions regarding the figure of Christ from Øravíkarlíð, Suðuroy. My colleague, Helgi D. Michelsen, is thanked for producing the map and aerial photo; and not least Arne Thorsteinsson, former State antiquarian of the Faroe Islands, my former boss, for discussions and engagement with this issue.

\section{Endnotes}

\footnotetext{
${ }^{1}$ Friedland 1973, 68.

2 Thór et al. 2012, 94.

${ }^{3}$ Zachariasen 1961, 162-167, 170ff.

${ }^{4}$ Arge and Mehler 2012, 178; Zachariasen 1961, 162-167.

${ }^{5}$ Arge and Michelsen 2004; Michelsen 2006.

${ }^{6}$ Arge and Michelsen 2004; Michelsen 2006.
} 
${ }^{7}$ Nolsøe and Jespersen 2004, 235. From 1524 until 1856 the trade with the Faroes was almost continuously carried on as a monopoly. From 1709/10 until its abolition in 1856, the monopoly was held by the Danish king.

${ }^{8}$ Debes 1673, 277.

${ }^{9}$ Arge and Mehler 2012.

${ }^{10}$ Debes 1995, 234; Thorsteinsson 1981.

${ }^{11}$ Arge and Michelsen 2004.

12 Thorsteinsson 1981.

${ }^{13}$ Degn 1942, 167.

${ }^{14}$ Helmsdal 1994.

${ }^{15}$ Thorsteinsson 1986.

${ }^{16}$ Degn 1942, 166.

${ }^{17}$ Kjærgård 1988, site number Fmnr. 55002/SNR:4824.

${ }^{18}$ Arge and Michelsen 2004; Michelsen 2006.

${ }^{19}$ Kjærgård 1988, site number Fmnr. 55002/SNR:8017.

${ }^{20}$ Thorsteinsson 1981.

${ }^{21}$ Krogh 1991.

${ }^{22}$ Degn 1942, 167: According to Degn this building was erected not later than the fourteenth century, though he is not refering to any source as base for his statement.

${ }^{23}$ Arge and Michelsen 2004.

${ }^{24}$ Michelsen 2006.

${ }^{25}$ Hamershaimb 1891, I, XXII.

${ }^{26}$ During the Avaldsnes conference in 2013 I had the opportunity to discuss these thoughts with Arne Thorsteinsson, who in fact had come upon that same idea. Since then I have considered the interpretation of Munkastovan further.

${ }^{27}$ Gardiner and Mehler 2007, 404f.

${ }^{28}$ Mehler 2012.

${ }^{29}$ Tonkin 1976.

${ }^{30}$ Arge and Mehler 2012.

${ }^{31}$ Debes 1673; Hamre 1950.

32 Debes 1673, 17: '...inderligt udi denne Fiord er en meget god liden Havn, kaldet Punthafn; nock en Holm mellem oc det fast Land, hvor mand kan binde Skibet fast med Landtove, oc paa en Fiæl gaa aff Skibet paa Landet. Ellers er der ofver det i Fiorden god Sommerhafn.' English translation by the author.

${ }^{33}$ Degn 1934.

${ }^{34}$ National Archives, Tórshavn: Nr. 47 Brev-Kopibog for Suderø Syssel 25 Febr. 1913 to. 2 Sept. 1913. (Nr. 150-818. 1913).

${ }^{35}$ Nolsøe and Jespersen 2004.

${ }^{36}$ Arge and Mehler 2012, 183f.; Mehler 2009, fig. 3.

${ }^{37}$ Mehler 2009, 100ff.

${ }^{38}$ Mehler 2009, 95 and fig. 3.

${ }^{39}$ Broockmann 1994, 107.

${ }^{40}$ Gardiner and Mehler 2007; Gardiner and Mehler 2010.

${ }^{41}$ Thorsteinsson 2012.

${ }^{42}$ Arge and Mehler 2012, 184f.

${ }^{43}$ Gardiner and Mehler 2007.

${ }^{44}$ According to an unpublished report named 'Skráseting av bygningum og støðum í Klaksvíkar kommunu at varðveita. Norðoya Fornminnissavn 1987' the Dutch had their búðir (booths) at the site; Hansen 1981.

${ }^{45}$ Bruun 1929, 100.

${ }^{46}$ Matras 1932, 134.

${ }^{47}$ Hansen 1978, 169; see also Brøgger 1937, 188.

${ }^{48}$ Hansen 1981.
${ }^{49}$ Arge 2005; Mahler 2007.

${ }^{50}$ Arge 1988, 290, note 5; Arge 1991, 113; Baug 2013.

${ }^{51}$ Malmros 1994.

${ }^{52}$ Arge 1992; Øye 2008.

${ }^{53}$ Arge 1997.

${ }^{54}$ Gaimster 2014; Thór et al. 2012, 132.

${ }^{55}$ Mehler and Gardiner 2013, 7.

${ }^{56}$ Krogh 1988; Arge 2008.

${ }^{57}$ Krogh 1991.

${ }^{58}$ Mortensen 2008; Thór et al. 2012, 92-102.

59 Thorsteinsson 1993; Arge and Mehler 2012; Thór et al. 2012, 100.

${ }^{60}$ Arge and Mehler 2012.

\section{References}

Andersen, N. 1895 (1964). Førøerne 1600-1709. Reprint. Tórshavn: Helge Justinussens Bókahandil.

Arge, S. V. 1988. Arkæologisk undersøgelse af middelalderlige bopladslevn i bygden Sandavágur. Hikuin 14, 285-296.

Arge, S. V. 1991. The Landnám in the Faroes. Arctic Athropology 28(2), 101-120.

Arge, S. V. 1992. Iron in the Faroe Islands. Usage, smithing and potential extraction, in A. Espelund (ed.), Bloomery Ironmaking during 2000 years. Seminar in Budalen, Sør-Trøndelag, Norway, August 26th - 30th 1991. Vol. II: Iron in the West Nordic Region during the Middle Ages, 17-29. Trondheim: Metallurgisk Institutt, Universitetet i Trondheim.

Arge, S. V. 1997. Í Uppistovubeitinum. Site and Settlement, Fróðskaparrit 45, 27-44.

Arge, S. V. 2005. Uttangarðs. Relics in the Faeroe outfield, in I. Holm, S. Innselset and I. Øye (eds), 'UTMARK'. The Outfield as Industry and Ideology in the Iron Age and Middle Ages, 67-82. University of Bergen Archaeological Series, International 1. Bergen: Universitetet i Bergen.

Arge, S. V. 2008. Kirkjubøur - Færøernes middelalderlige bispesæde. Monumenter og bevaring, in S. V. Arge and A. Mortensen (eds), Nordisk Ruinseminar Farøerne 18.-20. september 2007, 21-35. Hoyvík: Føroya Fornminnissavn.

Arge, S. V. and Mehler, N. 2012. Adventures far from home: Hanseatic trade with the Faroe Islands, in H. D. Harnow, D. Cranstone, P. Belford and L. Høst-Madsen (eds), Across the North Sea: Later historical archaeology in Britain and Denmark, c. 1500-2000 AD, 175-186. Odense: University Press of Southern Denmark.

Arge, S. V. and Michelsen, H. D. 2004. Fornfrøðiligar rannsóknir í gomlu Havnini, in J. P. A. Nolsøe and K. Jespersen (eds), Havnar Søga I, 23-52. Tórshavn: Tórshavnar kommuna.

Baug, I. 2013. Quarrying in Western Norway. An archaeological study of production and distribution in Viking Period and the Middle Ages. Bergen: University of Bergen.

Broockmann, H. 1994. Die Stadt im Späten Mittelalter. München: Beck Verlag.

Bruun, D. 1929. Fra de Farøske Bygder. Samlede afhandlinger om gammeldags Sad og Skik. Copenhagen: Gyldendal. 
Brøgger, A. W. 1937. Hvussu Føroyar vórðu bygdar. Løgtingssøga Føroya I. Tórshavn: Føroya Løgting.

Debes, H. J. 1995. Føroya søga II. Skattland og len. Tórshavn: Føroya Skúlabókagrunnur.

Debes, L. 1673. Farøernes Beskrivelse I and II. 1963 facsimilie edition by J. Rischel. Copenhagen: Munksgaard.

Degn, A. 1934 (ed). Kommissionsbetcenkningen 1709-10 ang. Farøernes Tilstand ved Kongens Overtagelse af Enehandelen paa Ferøerne. Tórshavn: A/S Færø Amtstidendes Bogtrykkeri.

Degn, A. 1942. Staðanøvn fram við sjónum frá Kirkjubønesi til Hoyvíkar. Varðin 22, 164-169.

Friedland, K. 1973. Der hansische Shetlandhandel, in Friedland, K. (ed.), Stadt und Land in der Geschichte des Ostseeraums, 66-79. Lübeck: Schmidt-Römhild Verlag.

Gaimster, D. 2014. The Hanseatic Cultural Signature: Exploring Globalization on the Micro-Scale in Late Medieval Northern Europe. European Journal of Archaeology 17(1), 60-81.

Gardiner, M. and Mehler, N. 2007. English and Hanseatic Trading and Fisching Sites in Medieval Iceland. Report on Initial Fieldwork. Germania 85, 385-427.

Gardiner, M. and Mehler, N. 2010. The Hanseatic trading site at Gunnister Voe, Shetland. Post-Medieval Archaeology 44(2), 347-349.

Hammershaimb, V. U. 1891. Færøsk Anthologi I. Copenhagen: Møller \& Thomsen.

Hamre, H. 1950 (ed). Færøers Beskrifvelser udi Største Korthed forfattet af Thomas Tarnovio Anno MDCLXIX den 24. Martij, Færoensia: Textus \& Investigationes 2. Copenhagen: Hafniae.

Hansen J. S. 1978. Tey byggja land, vol. 5: Húsa og Mikladals sókn. Klaksvík: Egið forlag.

Hansen, J. S. 1981. Tey byggja land, vol. 7: Klaksvíks sókn. Seinna helvt. Klaksvík: Egið forlag.

Helmsdal, M. 1994. ... verjir fyri Havnarvág. Tórshavnar Havn í søguni. Tórshavn: M. Helmsdahl.

Kjærgård, A. 1988. Udgravningsrapport for de arkæoologiske undersøgelser på Tinganes, Tórshavn. Unpublished report.

Krogh, K. J. 1988. Kirkjubøstolene og Kirkjubøur. Et brudstykke af det farøske bispesæedes historie. Tórshavn: Emil Thomsen.

Krogh, K. J. 1991. Sankt Brandanus og Kirkjubøur. Faroe Isles Review 1, 30-37.

Mahler, D. L. 2007. Sateren ved Argisbrekka. Økonomiske forandringer på Førøerne $i$ vikingetid og tidlig middelalder, Annales Societatis Scientiarum Faeroensis, Supplementum 47. Tórshavn: Faroe University Press.

Malmros, C. 1994. Exploitation of Local, Drifted and Imported Wood by the Vikings on the Faroe Islands.
Archaeobotany. Botanical Journal of Scotland 46(4), 552-558.

Matras, C. 1932. Stednavne paa de ferøske Norðuroyar. Aarbøger for nordisk Oldkyndighed og Historie. Copenhagen: Det Kongelige Nordiske Oldskriftselskab.

Mehler, N. 2009. The perception and interpretation of Hanseatic material culture in the North Atlantic: problems and suggestions. Journal of the North Atlantic, Special Volume 1, 89-109.

Mehler, N. 2012. Thing-, Markt- und Kaufmannsbuden im westlichen Noreuropa. Wurzeln, Gemeinsamkeiten und Unterschiede eines Gebäudetyps. Mitteilungen der Deutschen Gesellschaft für Archäologie des Mittelalters und der Neuzeit 24, 71-82.

Mehler, N. and Gardiner, M. 2013. On the verge of colonialism: English and Hanseatic trading sites in the North Atlantic Islands, in P. Pope and S. LewisSimpson (eds), Exploring Atlantic Transitions: Archaeologies of Permanence and Transition in New Found Lands, 1-14. Woodbridge: Boydell and Brewer.

Michelsen, H. D. 2006. Tórshavns bebyggelsestopografi frem til 1673. En arkaologisk vurdering set $i$ lyset af de historiske kilder. Unpublished Master's thesis, University of Aarhus.

Mortensen, A. 2008. Muren og det færøske bispesæde i senmiddelalderen - Byggevirksomhed og økonomi, in S. V. Arge and A. Mortensen (eds), Nordisk Ruinseminar Ferøerne 18.-20. september 2007, 10-20. Hoyvík: Føroya Fornminnissavn.

Nolsøe, J. P. A. and Jespersen, K. 2004. Havnar Søga I. Tórshavn: Tórshavnar kommuna.

Thorsteinsson, A. 1981. Tinganes 1673. Fróðskaparrit 28/29, 293-312.

Thorsteinsson, A. 1986. Tinganes - Tórshavn. En kort historisk orientering. A Brief Historical Guide. Tórshavn: Føroya Landsstýri.

Thorsteinsson, A. 1993. Merkur, alin og gyllin, Frøði 1, 4-9.

Thorsteinsson, A. 2012. District Thingsteads in the Faroe Islands, in O. Owen (ed.), Things of the Viking World, 55-67. Lerwick: Shetland Amenity Trust.

Thór, J. Th., Thorleifsen, D., Mortensen, A. and Marquardt, O. (eds) 2012. Naboer i Nordatlanten. Farøerne, Island og Grønland. Hovedlinjer $i$ Vestnordens historie gennem 1000 år. Tórshavn: Faroe University Press.

Tonkin, J. W. 1976. Two Hanseatic Houses in the Shetland. Hansische Geschichtsblätter 94, 81-82.

Øye, I. 2008. Kontakten mellem Bergen og Færøyene i middelalderen i arkeologisk og historisk lys, in C. Paulsen and H. D. Michelsen (eds), Símunarbók. Heiðursrit til Símun V. Arge á 60 ára degnum, 243-252. Tórshavn: Faroe University Press.

Zachariasen, L. 1961. Føroyar sum rættarsamfelag 1535-1655. Annales Societatis Scientiarum Færoensis, Suppelementum IV. Tórshavn: Føroya Fróðskaparfelag. 